\title{
The implementation of guidance and counseling services in overcoming the cheating habits of high school students
}

\author{
Taufik Agung Pranowo, Ardhian Rohmad Santoso \\ Universitas PGRI Yogyakarta \\ taufikagung@upy.ac.id
}

Submitted: 25-09-2020, Revised: 24-08-2021, Accepted: 14-11-2021

\begin{abstract}
This study aims to determine the implementation of guidance and counseling services conducted by the counselor at SMA N 1 Pajangan in overcoming student cheating problems. Research conducted in this study uses qualitative methods with a descriptive approach. There are two data used in this study, namely primary data and secondary data. Data collection techniques are used observation and interviews. The data analysis used was data reduction, data creation, and conclusions. The result of this study is counselors provide guidance and counseling services to overcome cheating behavior by collaborating with subject teachers. The services cover student experiences with motivation. The conclusion is the role of guidance and counseling teachers on students' cheating habits is very good. There is a cooperation between counselors and subject teachers to be able to overcome this problem.
\end{abstract}

Keywords: Cheating; Counselor; Guidance and Counseling

\section{Introduction}

Education cannot be separated from an educator whose role is to educate, teach a science, guide, train, provide assessments and evaluate students. The educator in question is a person who is a professional according to his field called a teacher. Teachers are one of the important factors in the implementation of education. One of which is a counselor who is responsible for implementing guidance and counseling. Regulation of the Minister of Education and Culture number 111/2014 concerning Guidance and Counseling in Basic Education and Secondary Education states that Guidance and Counseling as an integral part of the education program is an effort to facilitate and make students independent to achieve complete and optimal development.

Guidance and counseling activities in schools are realized in an organized and planned program. The guidance and counseling program will be implemented effectively, if it is based on the real needs and objective conditions of the student's development (Kurniawan, 2015; Sari et al., 2020). About this, the role of counselors in schools is essential. They provide guidance and counseling services in facilitating the development of self-learners according to their interests, talents, and expensive stages of development tasks. By given the diversity of individual students as well as the diversity of abilities of guidance and counseling teachers in schools, it is necessary to emphasize that the implementation of guidance and counseling in schools must refer to the program to accommodate Law No. 20 of 2003 and government regulation no. 19 of 2005 and the regulations that accompany it (Nasional, 2005).

School counselors have the responsibility of providing guidance and counseling services, being aware of the personality development and abilities of students (Cross \& Cross, 2021; Mulyadi, 2016; Tjalla, 2020). In this case, it is expected that the teachers can carry out their duties and roles according to the rules that have been set. The results given can solve the problems faced by students. The achievement of the goals of guidance and counseling should be in synergy with the achievement of educational purposes in general so that the performance of counselors as a manifestation of the competencies that surround them can be optimal (Ralasari S \& Atika, 2019; Thahir et al., 2021). At that time, the counselor profession was legally formally recognized in the national education system. Counselor is a profession that has been recognized for its existence in schools. 
Counseling Guidance is the process of providing services by the counselor to the counselee directly to help the counselee get out of his problem. The provision of guidance and counseling services in schools is expected to help students to actualize themselves which is carried out to achieve better performance (Rimonda et al., 2018; Winkel \& Hastuti, 2010). The role of the counselor is crucial in realizing and developing the potential of students by taking preventive actions, developing and caring for students.

The counselors should facilitate good and optimal service to all students. It should be tailored to the needs of students in schools so that they are right on target, have goals, and have an effect on changing students' behavior (Yandri, 2014). Guiding and educating cannot be separated from the duties and responsibilities of teachers, including the counselor. As educators, counselors have full duties, responsibilities, and authority in guidance and counseling activities for students. It is to help students find their identity, adapt to the environment, and be able to plan for their future so that they can improve optimally (Havlik et al., 2019; Lattu, 2018; Lee, 2018; Randick et al., 2018).

Steps that counselors can take in uncovering learning problems are by practicing content mastery, helping to optimize the counselee's personal and skills, and maximizing facilities and infrastructure (Ayannuga, 2020; Handono \& Bashori, 2013; Hartanto et al., 2021). They should help counselees develop effective study habits through content or tutoring services to improve their quality. Learning difficulty is one of the causes of cheating behavior. It is a symptom or condition in the teaching and learning process which is characterized by certain obstacles to achieving learning outcomes (Ahmad, 2011; Onabamiro \& Odunlami, 2017). Therefore, overcoming an obstacle is part of the learning process in schools. Teachers as education personnel are responsible for dealing with students' learning difficulties for advancement in the ongoing learning or forthcoming learning.

The issue of cheating often occurs in the world of education whether in Indonesia or overseas. It is faced by all countries. This crisis became an international concern (Abdulghani et al., 2018; Hartono, 2018), and bothered because many students are expected to become future leaders (Abdulghani et al., 2018; Meiseberg et al., 2017). Cheating factors are influenced by gender, peer pressure, and fear of significant failure (Ifeagwazi et al., 2019). Male students cheated constantly than female students and students with lower academic grades cheated repeatedly (Ghanem \& Mozahem, 2019). It occurs at every level of education, from junior high school to university level. Four factors influence the demeanor, namely; 1) desire to get high scores, 2) educational environment, 3) difficulties encountered, and 4) lack of educators quality (Brown \& Choong, 2003). Perception plays a key role in defining students' performance. The more the students perceive that others are engaging in a certain act, the higher the probability that they will engage in the nature, even if they believe that this demeanor constitutes cheating (Rimonda et al., 2020). Existing factors need to be analyzed to find out how to prevent cheating so that it can be minimized or even eliminated from students' habits.

In confounding this situation, guidance and counseling services have a central role. The results of the observations showed that the counselors of SMAN 1 Pajangan had taken preventive actions to subdue students' cheating behavior. The role of the counselor is vital in the continuity of teaching and learning activities, as a supervisor as well as help in dealing with various problems experienced by students. With the counselor in the school institution, it is possible to solve a problem, including the trouble of low student achievement. The presence of guidance and counseling supports the goals of national education, namely seeking the students' personality and potential development (Galassi, 2017; Prayitno \& Amti, 2004).

The data assembled from counselors showed that many students do not hesitate to copy their friends' assignments or exam sheets. They make and use small notes or open 
books during exams, access the internet, and so on. By looking at those conditions, a counselor who handles counseling services needs to have more specific requirements than other teachers to be able to approach various dilemmas confronted by students while helping to find alternative solutions (Nisa, 2018; Weissman et al., 2017). If this is allowed, students will experience various kinds of hardships such as not believing in themselves which will certainly hinder their progress and career. Therefore guidance and counseling teachers need to pay attention to the problem of students cheating because their help can vanquish the danger students are experiencing.

\section{Method}

This research was conducted at Pajangan 1 Public Senior High School (SMA N 1 Pajangan) which is located at Kedung, Guwosari, Pajangan, Bantul, Yogyakarta Special Region. It was chosen because the high school has a good reputation for learning so that researchers assess the potential for schools to develop rapidly. The role of the guidance and counseling teacher at SMA N 1 Pajangan is good in handling issues experienced by students, one of which is cheating.

This study uses a qualitative descriptive approach. The first step in this research was observing the object so that the researcher can understand the actual situation. It is a nonparticipatory action where the researcher is outside of the system being observed. With these observances, the researcher determined the objectives in this study, namely students and guidance services by counselors. The next step was interviewing the informants (principals, subject teachers, counselors, and students) through direct conversation. The last was documenting a record of events in written form or monumental works by students.

The data used in this study are primary and secondary. The former was obtained directly from counselors through interviews. The latter is obtained indirectly through a second or third source. The subjects in the secondary data collection were the principal, homeroom teacher, subject teachers, and so the others who were in SMA N 1 Pajangan. The data collection techniques used were observation and interview. While the instruments used in this study were observation and interview guidelines.

The analysis uses data reduction by summarizing, selecting, and focusing on the main and important things, looking for themes and patterns. The following stage is presenting data to make it easier for readers to understand field conditions and then planning a program based on the data that has been collected. The next step is the researcher concludes the study. The initial conclusions put forward are still provisional and can change if strong evidence is not found to support them at the next data collection stage. The conclusion of qualitative research will be able to answer the formulation of problems which is still temporary and will develop after field research. The validity of the data obtained by the researcher needs to be checked through triangulation techniques.

\section{Results and Discussion}

Based on the results of interviews, observations, and documentation by the counselor at SMA N 1 Pajangan, it shows that students of SMA N 1 Pajangan already have learning arrangements, but there are several students with the habitual cheating act. Students show cheating demeanor with real behavior in the form of seeing friends' answers, exchanging answers using hand codes, and looking at material books. Fishbein and Ajzen (Nursalam, 2012) suggest that there are four aspects of cheating attitude as follows:

a. The nature manifested by students is in the form of cheating by seeing, copying, imitating other students' answers during exams. 
b. Cheating management targets; The target object is in the form of answer notes, books, cellphones, calculators, or friends.

c. In situations that support students to apply cheating performance; they will see how and where the action will be manifested. It can also be interpreted as the location of the practice. In the context of cheating, this habit can arise if students feel they are in a pressing situation, for example, a sudden examination is held, too much test material or there are several exams held on the same day so that students feel they have less time to study. Another situation that encourages students to cheat is the student feels that his actions will not be caught; even though he is, the student feels the punishment they receive is not burdensome.

d. The time of the occurrence of cheating behavior; includes a certain time (certain day, certain time, and certain hour), certain period (certain month), and unlimited time (future time).

Subject teachers told researchers in an interview, they conveyed material to students according to existing procedures and gave assignments to students according to the topic they had learned. They supervise exams in class, warn students not to cheat, and motivate students to be more confident when dealing with the assessment.

Counselors at SMA N 1 Pajangan have adequate space so that they can procure group guidance services, individual counseling, and other services properly. Communication with researchers is also decent and thoughtful so that researchers can find out what is being studied. There is also an annual program in the guidance and counseling teacher room that makes it manageable for the teachers to carry out services for students who have difficulty.

The counselors have been pursuing several strategies, such as giving advice and warnings that cheating is unacceptable. However, because not all subject teachers have strict regulations and have the same notion of the bad impact from it, students' habit of cheating has not been reduced properly. A cooperative attitude between teachers and parents will help students to excel. Counselors implement counseling services to prevent cheating and eliminate it. They do it by collaborating with parents to change impressions. They know that grades are not everything and it is better to understand students' ability level. They carry out strategies to reduce cheating by using textbooks that are organized, good, and helpful in the learning process.

Counselors carry out their roles well, motivate students, and change students' cheating habits, and students are motivated to follow the guidelines from them. Students with this habit began to decrease and this became strong evidence that the counselor had played his/her role well. Character education goals can be realized by dealing with and solving problems faced by students. This regulation refers to a law that has been passed by the government, guidance and counseling services in schools have now obtained clearer legalformal legality, namely The Regulation of the Minister of Education and Culture No. 111 of 2014 concerning guidance and counseling in primary and secondary education. It becomes an important reference for counselors in providing guidance and counseling services in schools.

The counselor plays a good role and is following the procedures for arousing student motivation, optimizing student development, and giving gifts as an encouragement to do good things. It is proven by students who experience less habitual problems of cheating and the crisis is decreasing.

Teacher as motivation generator to learn. It is done by guidance and counseling teachers can specifically use lesson hours or tucked in while teaching or providing exercises. Besides, guidance and counseling teachers must also make efforts to arouse student learning motivation, including: 
1. The teacher explains the benefits and objectives of the lessons given. Learning with clear goals and profits for students will generate motivation.

2. The teacher chooses teaching materials according to the needs of students so that they will attract students' interest.

3. The teacher chooses a variety of presentation methods, according to students' abilities and provides many opportunities for students to try and participate. Doing lots of things in learning will be more uplifting than just listening.

4. Provide opportunities for students to achieve success. The success will generate motivation to learn, and conversely, a failure that occurs in students can eliminate motivation.

5. Providing convenience and assistance to students in the learning process. The teacher's job is to help optimize the development of students. For the development of students to run smoothly, the teacher provides facilities in learning and does not complicate learning development experienced by students. The teacher helps students who have difficulties or obstacles in learning, giving instructions such as who or where to ask for help.

6. Giving praise, rewards, or prizes to motivate students to learn. Therefore, Guidance and Counseling teachers need to create various student activities in the classroom (Daryanto, 2015)

In solving the problem of habitual cheating, the guidance and counseling teachers cannot be separated from the collaboration with the principal, subject teachers, homeroom teachers, and guardians of students. This collaboration is an effective way to alleviate the issue. By using this method, all parties can control students' activities while at school or home so that students can endure the dilemma of their habit properly. Collaboration is carried out by two or more parties. It is a form of social process, in which there are certain activities aimed at achieving common goals by helping and understanding each other's activities (Abdulsyani, 2007; Epstein, 2018; Rock et al., 2017).

Implementation of services by counselors requires cooperation with various parties. Counselors must understand the characteristics of students, plan, implement, evaluate and follow up on guidance and counseling programs to withstand the situation on an ongoing basis so that the hardships discovered by students can be resolved optimally.

\section{Conclusions and Suggestions}

Most of the students have good learning arrangements already and some need to continue to be guided, directed, and supervised. The student's act shows true nature in the form of seeing friends' answers, exchanging answers using hand codes, and looking at material books. This is actual action students do during the exam.

The role of the counselor in SMA N 1 Pajangan display on the habit of cheating on students is very good. There is a collaboration between counselors and subject teachers to be able to confound students' cheating acts. Guidance and counseling programs need to be implemented in the services provided by the counselor. The counselor can vanquish students' cheating habits by continuing to motivate and encourage students to compete healthily.

\section{References}

Abdulghani, H. M., Haque, S., Almusalam, Y. A., Alanezi, S. L., Alsulaiman, Y. A., Irshad, M., Shaik, S. A., \& Khamis, N. (2018). Self-reported cheating among medical students: An alarming finding in a cross-sectional study from Saudi Arabia. PLoS One, 13(3), e0194963. 
Abdulsyani. (2007). Metodologi penelitian sosial dan hukum. SAGE, 8(2), 1-23.

Ahmad, R. (2011). Model penyiapan siswa menghadapi ujian akhir. Studi Pada Siswa Kelas III Di SMA Padang).(Disertasi). Tidak Dipublikasikan.

Ayannuga, O. M. (2020). Implementation of universal basic education programme in Lagos state schools: Counsellors' and teachers' perceptions. Journal of Guidance, 4(2), 363373.

Brown, B. S., \& Choong, P. (2003). Identifying the salient dimensions of student cheating and their key determinants in a private university. Journal of Business \& Economics Research (JBER), 1(3).

Cross, T. L., \& Cross, J. R. (2021). Handbook for counselors serving students with gifts and talents: Development, relationships, school issues, and counseling needs/interventions. Routledge.

Daryanto, M. F. (2015). Bimbingan konseling panduan guru bimbingan konseling dan guru umum. Yogyakarta: Gava Media.

Epstein, J. L. (2018). School, family, and community partnerships in teachers' professional work. Journal of Education for Teaching, 44(3), 397-406.

Galassi, J. P. (2017). Strengths-based school counseling: Promoting student development and achievement. Routledge.

Ghanem, C. M., \& Mozahem, N. A. (2019). A study of cheating beliefs, engagement, and perception: The case of business and engineering students. Journal of Academic Ethics, 17(3), 291-312.

Handono, O. T., \& Bashori, K. (2013). Hubungan antara penyesuaian diri dan dukungan sosial terhadap stres lingkungan pada santri baru. Empathy, 1(2), 79-89.

Hartanto, D., Amir, Z., \& Muhandaz, R. (2021). Indigenous counseling and multiculture learning at secondary schools in $3 \mathrm{t}$ region (left behind, frontier, and outermost) in Indonesia. HISPISI: Himpunan Sarjana Ilmu-Ilmu Pengetahuan Sosial Indonesia, 1(1), 1-17.

Hartono, M. S. (2018). Bimbingan karier. Prenada Media.

Havlik, S. A., Malott, K., Yee, T., DeRosato, M., \& Crawford, E. (2019). School counselor training in professional advocacy: The role of the counselor educator. Journal of Counselor Leadership and Advocacy, 6(1), 71-85.

Ifeagwazi, C. M., Chukwuorji, J. C., Egbodo, S. O., \& Nwoke, M. B. (2019). Peer pressure, fear of failure and examination cheating behavior in the university: Does gender make the difference? Cognition, Brain, Behavior, 23(1), 43-62.

Kurniawan, L. (2015). Pengembangan program layanan bimbingan dan konseling komprehensif di sekolah menengah atas. Jurnal Psikologi Pendidikan \& Konseling, $1(1), 1-8$.

Lattu, D. (2018). Peran guru bimbingan dan konseling pada sekolah penyelenggara pendidikan inklusi. Jurnal Bimbingan Dan Konseling Terapan, 2(1).

Lee, C. C. (2018). Counseling for social justice. John Wiley \& Sons.

Meiseberg, B., Ehrmann, T., \& Prinz, A. (2017). "Anything worth winning is worth cheating for"? Determinants of cheating behavior among business and theology students. Journal of Business Economics, 87(8), 985-1016.

Mulyadi, R. D. (2016). Bimbingan konseling dan islam di madrasah dan sekolah. Jakarta: PT. Kalam Mulia.

Nasional, D. P. (2005). Peraturan pemerintah nomor 19 tahun 2005. Tentang Standar Nasional Pendidikan.

Nisa, A. (2018). Peran guru bimbingan dan konseling dalam meningkatkan minat melanjutkan studi ke perguruan tinggi. Konseli: Jurnal Bimbingan Dan Konseling (EJournal), 5(1), 1-8. 
Nursalam, N. (2012). Intensitas copying answer pada tes kemampuan matematika. Lentera Pendidikan: Jurnal Ilmu Tarbiyah Dan Keguruan, 15(1), 32-40.

Onabamiro, A. A., \& Odunlami, I. A. (2017). Relationship between study habits and secondary school student's academic performance in eti osa local government area of lagos state. Nigerian Academic Forum, 23(1), 1-6.

Prayitno, E. A., \& Amti, E. (2004). Dasar-dasar bimbingan dan konseling. Jakarta: Rineka Cipta.

Ralasari S, T. M., \& Atika, A. (2019). Pelaksanaan program bimbingan belajar di dekolah menengah atas kota Pontianak. JBKI (Jurnal Bimbingan Konseling Indonesia), 4(1), 31. https://doi.org/10.26737/jbki.v4i1.844

Randick, N. M., Dermer, S., \& Michel, R. E. (2018). Exploring the job duties that impact school counselor wellness: The role of RAMP, supervision, and support. Professional School Counseling, 22(1), 2156759X18820331.

Rimonda, R., Bulantika, S. Z., Latifah, H., \& Khasanah, I. (2020). The influence of cinematherapy against academic anxiety in students. Jurnal Inspirasi Pendidikan, 10(1), 57-62.

Rimonda, R., Wibowo, M. E., \& Jafar, M. (2018). The effectiveness of group counseling by using cognitive behavioral therapy approach with cinematherapy and self-talk techniques to reduce social anxiety. Jurnal Bimbingan Konseling, 7(2), 145-152.

Rock, W. D., Remley, T. P., \& Range, L. M. (2017). Principal-counselor collaboration and school climate. NASSP Bulletin, 101(1), 23-35.

Sari, P., Bulantika, S. Z., Dewantari, T., \& Rimonda, R. (2020). Effects of stress coping and emotion regulation on student academic stress. Konseli: Jurnal Bimbingan Dan Konseling (E-Journal), 7(1), 73-80.

Thahir, A., Gustina, Yetri, Bulantika, S. Z., Sari, P., Rimonda, R., \& Dewantari, T. (2021). Respiratory system: A learning content development system-based student worksheet in biology. IOP Conference Series: Earth and Environmental Science, 1796(1). https://doi.org/10.1088/1742-6596/1796/1/012069

Tjalla, A. (2020). The Influence of the prevention, advocacy, distribution, repair, and adjustment functions of teacher guidance and counselling on the psychosocial conditions, self-reliance, and competence of high school students in Jakarta province. International Journal of Education and Practice, 8(1), 174-189.

Weissman, M. M., Markowitz, J. C., \& Klerman, G. L. (2017). The guide to interpersonal psychotherapy: Updated and expanded edition. Oxford University Press.

Winkel, W. S., \& Hastuti, S. (2010). Bimbingan konseling di institusi pendidikan. Jakarta: Grasindo.

Yandri, H. (2014). Peran konselor dalam pencegahan tindakan bullying di sekolah. Jurnal Pelangi, 7(1). 
